\title{
Adherence to Public Procurement Act in Tamale Polytechnic of Ghana: Rhetoric or Reality in practice?
}

\author{
Charles Adusei \\ Department of Accounting, Finance and Banking \\ Faculty of Business Studies, Garden City University College, Kumasi, Ghana \\ Stephen Laar \\ Procurement Unit, Tamale Polytechnic \\ Tamale, Ghana
}

\begin{abstract}
This paper examines the Public Procurement Act (PPA) 2003 (Act 663) on its adherence by Tamale Polytechnic. The key issues considered included procurement practices before and after the implementation of PPA. A wellstructured questionnaire was used in collecting data from the staffs. Descriptive statistics, One Sample t-Test and Kendall's Coefficient of Concordance were used to analyse the data. Result revealed that strict procurement procedures were not followed prior to PPA, though PPA brought sanity into the Polytechnic in their procurement processes, its implementations were bedeviled with a lot of challenges. This paper suggests that management of the Polytechnic should allow the procurement unit to operate freely without any form of interference in its quest to adhere to the PPA (Act 663).
\end{abstract}

Key words: Public Procurement Act, Tamale Polytechnic, Adherence, Ghana

\section{INTRODUCTION}

The Government of Ghana enacted the Public Procurement Act, 2003, (Act 663) in December, 2003. The Act became effective/operational on 27th of August 2004, hence the Public Procurement Act of Ghana (PPA). The PPA provides general guidelines on regulations and administrative instructions governing procurement in public institutions. Public Procurement Act, 2003 is to ensure that public procurement is carried out in a fair, transparent and nondiscriminatory manner.

The PPA 2003 actually came into the system to help streamline administrative procedures in government institutions since the World Bank [1] reported that $60 \%$ to $70 \%$ of government expenditure was procurement related after emoluments. The Act came in as a remedy to save this situation in which the country had found itself by effecting the needed operational methods to guide and monitor procurement activities. There was no outlined policy or existing frame work for public procurement activities, institutional arrangement, documentation and central body for procurement according to Suleiman [2]. Good procurement system could bring some sanity into government expenditure thereby ensuring value for money for a developing country like Ghana. This challenge remains unchanged up to date.

Prior to the enactment of the PPA 2003 (Act 663), Ghana National Procurement Agency (GNPA) and Ghana Supply Company Limited (GSCL) were the main agents that procured all public goods for the government since there was no comprehensive procurement guidance by 
Adjei [3]. These bodies were not regulating public procurement but purchasing goods, services and awards of contracts on behalf of public entities. As there was no comprehensive legal regime and a central body with the responsibility to harmonize procurement process in the country, more and more sector ministries such as the Ministry of Health (MOH) decided to implement their own procurement system. According to Adjei [3], some of these institutions were to ensure that their funds were judiciously used.

The World Bank was one of the institutions that wanted to ensure that their funds were judiciously used. The World Bank introduced its procurement guidelines for all World Bank Projects by World Bank Report [4]. Traditional procurement methods were used for public works with provisions for compulsory registration and classification of suppliers and contractors administered by the Ministry of Water Resources, Works and Housing. The monetary thresholds - were not regularly rationalized as indicated by the World Bank Report [1] and Eyiah and Cook [5] when procurement entities were procuring. Since 1999, the Ministry of Finance has made tremendous efforts at developing a National Procurement Code using the achievements in procurement at the Ministry of Health as an example to largely regulate procurement through the issuance of circulars. This complements a set of procedures that evolves from conventions that were connected with procurement control by the Ministry.

Major and complex contracts that were financed by the government through architectural consultancy services and project supervision were assigned to the Architectural and Engineering Services Limited (AESL) on single basis without recourse to fair competition as reported in World Bank Report, [1]. These uncoordinated and unregulated systems of procurement were the consequences of poor procurement situation leading to the much acclaimed reform of public procurement practices to instill trust and confidence in the public and the donor community by Kotoka [6]. From development point of view, public procurement policies are significant. Reducing poverty and attaining health, education, and other objectives among the citizenry requires that the limited public funds available for public procurement of goods, services, and works are properly managed according to Kotoka [6]. Generally, the efficient, effective and professional application of public procurement laws can contribute towards sound management of public expenditures as suggested by Hunja [7]. Furthermore, there is a growing appreciation of the linkages between specific public sector objectives and public procurement practices. For instance, public procurement issues are often a central focus programmes to deal with corruption and to ensure that appropriate entrusted power for private gain by public officials are curbed by Evenett and Hoekman [8].

In a research conducted by Ameyaw, et al, [9], public procurement in Ghana revealed low capacity of procurement professionals, low interaction between procurement entities and Public Procurement Authority, deliberate controlling of competition, non-compliance with provisions of the law, splitting of contracts into smaller lots, lack of funds and noncooperativeness of suppliers, as the major challenges militating against the implementation of the Public Procurement Law. In addition lack of financial constraints to employ and train procurement staff to facilitate the implementation of the procurement procedures. The PPA has not also been able to train suppliers and contractors on tendering procedures in other to help them know their right and avoid any cheating. Political interference with the procurement process is also seriously affected the operations as procurement staff are always manipulated by politicians on their work as reported by World Bank [10], and delays in payment of contractors and suppliers have also been cited as some of the crucial factors that challenges the procurement reforms implementation by Azeem [11]. 


\section{METHODOLOGY}

Primary data was used in this study and it was collected from the staffs of the Tamale Polytechnic through a self-administered structured questionnaire. A likert scale was used to indicate the responses from the staffs to measure the procurement activities of Tamale Polytechnic. The population for the study is made up of the entire staff of Tamale Polytechnic. The targeted departments included the Deans of Schools, Heads of Departments and the Procurement Unit. The study adopted the non-probability sampling approach but the focus was on purposive sampling where the study selected the staffs based on a laid down checklist which made it possible to discriminate to get the appropriate sample size. The sample size was fifty based on the criteria that the person must be an authorising officer, the person is involve in buying items for the institute and is prepared to fill the questionnaire voluntarily. The study was cross sectional and survey strategy fit it well.

\section{Analytical framework}

Descriptive statistics such as frequency tables and percentages were used to present the sociodemography characteristics of the staffs. The Mean was use as a measure of central tendency whiles the Standard Deviation as a measure of dispersion. The high mean value correspond to "agree" in their responses while a low standard deviation explains the degree of consensus to the factors outlined.

Inferential statistics for comparing means in the type of One Sample t-Test was used. The test statistic for a One Sample $(\mathrm{t})$ analysis was used on the respondents view on procurement practices after the PPA (Act 663).

\section{Hypotheses}

The null hypothesis $\left(H_{o}\right)$ and (two-tailed) alternative hypothesis $\left(H_{1}\right)$ of the one sample T test is expressed as:

$H_{o}: \mu=0$ [Non adherence of a factor to the PPA (Act 663)]

$H_{1}: \mu \neq 0$, [Adherence of a factor to the PPA (Act 663)]

The decision rule involves comparing the hypothesized population mean (i.e. the test value) and expected mean (test statistic). The result is considered statistically significant if the pvalue is less than chosen alpha level. The null hypothesis must be rejected.

The test statistic for a One Sample $(t)$ Test is denoted $(t)$, which is calculated using the following formula:

$$
t=\frac{x-\mu}{s_{x}}
$$

Where:

$$
s_{x}=\frac{s}{\sqrt{n}}
$$

Where:

$\mu=$ proposed constant for the population mean

$\mathrm{x}=$ sample mean

$\mathrm{n}=$ sample size (i.e., number of observations)

$\mathrm{s}=$ sample standard deviation

$\mathrm{Sx}=$ estimated standard error of the mean 
Kendall's coefficient of concordance (W) analysis was used to rank the items identified as PPA effects on procurement practices and implementation challenges of PPA. The degree of agreement of the rankings by the staffs was then measured. W ranges from 0 to 1 . In deriving $\mathrm{W}$, let $\mathrm{T}$, represent the sum of ranks for each procurement practices, its effects and challenges being ranked. The variance of the sum of ranks is given by:

$\operatorname{Var}_{T}=\frac{\sum T^{2}-\left(\sum T\right)^{2} / n}{n}$

Where denotes variance and denotes the number of effect and challenges of PPA. The maximum variance of is given by

$m^{2}\left(n^{2}-1\right) / 12$

Where is the number of respondents? The formula for Kendall's coefficient of concordance is given by

$W=\frac{\left(\sum T-\left(\sum T\right)^{2} / n\right) / n}{m^{2 *}\left(n^{2}-1\right) / 12}$

By simplifying equation 3 above, the result in the computational formula for as:

$W=\frac{12\left[\sum T^{2}-\left(\sum T\right)^{2} / n\right]}{m n^{2}\left(n^{2}-1\right)}$

\section{General characteristics of the studied respondents}

RESULTS AND DISCUSSION

This section considers the characteristics of the respondents as shown in Table1 as shown below.

Table 1: Socio-demographics of the respondents

\begin{tabular}{|l|r|r|}
\hline Variables & Frequency (N =50) & \% \\
\hline Gender & & \\
Male & 37 & 74 \\
Female & 13 & 26 \\
\hline Length of service (years) & & \\
$5-10$ & 36 & 72 \\
$15-20$ & 11 & 22 \\
$>30$ & 3 & 6 \\
\hline Level of Education & 1 & 2 \\
Doctorate & 29 & 58 \\
Master Degree & 12 & 24 \\
Bachelor Degree & 5 & 10 \\
Diploma & 3 & 6 \\
Secondary & & \\
\hline Nature of Employment & 48 & 96 \\
Full time & 1 & 2 \\
Part time & 1 & 2 \\
Casual &
\end{tabular}

Source: Fieldwork, 2015

Table 1 describes the general characteristics of the respondents, among the fifty (50) studied, (74\%) were males, (72\%) length of service in between 5-10 years, (29\%) were Master Degree holders at the educational level and (96\%) are full time staffs. The respondent's knowledge on 
the PPA activities is critical to its adherence and favourable outcomes to bring about value for money for Tamale Polytechnic especially with the procurement unit. In addition, user departments principally the authorizing officers must have adequate knowledge on the PPA.

Regarding the socio-demographic characteristics of the sampled respondents the result of this study showed that specific characteristics such as gender and nature of employment are insignificant variables in affecting the adherence of the PPA. One cannot ignore the fact that most of the employees in Tamale Polytechnic were full time staffs. As a result, they are likely to be acquainted with procurement practices in the institution. This is contrast to Adusei and Awunyo-Vitor [12]; they reported in their study that gender characteristic is crucial as an indication of possible thievery and corruption acts.

The number of years worked can help to understand the extent to which the respondents' could contribute meaningful information on the issue of procurement practices in the institution. The findings indicate that majority of the respondents had ample working experience in the Polytechnic. This, therefore, shows that the respondents could have in-depth information on the procurement practices in the institution. Length of service is tempting but does not guarantee that they will do the right thing, this is in agreement with Bower [13] who suggested that the number of years that respondents have spent in their workplace can determine their experience which will influence their level of understanding as well as the extent to which they could comply with the Public Procurement Act.

Considering the educational level, the present study revealed that there is assumed association between the level of education and procurement activities. The agreement here should be $60 \%$ and more by the combination of "agree" and "strongly agree". Based on this, there is agreement in the area of preparation of procurement plan before procurement and independent panel of $66 \%$ respectively while entity tender committee processes and procedures; and fairness of tendering process of $68 \%$ respectively. The finding reflects the literate nature of the Polytechnic staffs and the ability of the staffs to offer meaningful contribution to the study through their views on the key issues under investigation could not be in doubt. It can be inferred that respondents who had tertiary education are likely to adhere to good practices of procurement activities through the PPA. This confirms World Bank [4] introduced the procurement guidelines, the findings of the result is an extension to that statement as having guidelines are not enough but having knowledgeable personnel who are committed to follow the instructions/guidelines to its letter.

\section{Procurement practices before the PPA}

Table 2: Respondent's views on procurement practices before the PPA

\begin{tabular}{|l|l|l|l|l|l|l|}
\hline & \multicolumn{3}{|c|}{ Yes } & \multicolumn{3}{c|}{ No } \\
\hline Aspects attached to procurement activities & $\mathrm{N}$ & $\%$ & $\mathrm{~N}$ & $\%$ & $\mathrm{~N}$ & $\%$ \\
\hline Follow due processes on procurement & 24 & 48 & 15 & 30 & 11 & 22 \\
\hline $\begin{array}{l}\text { There was proper documentation for approval on } \\
\text { tender documents }\end{array}$ & 21 & 42 & 16 & 32 & 13 & 26 \\
\hline $\begin{array}{l}\text { Request for procurement were always approved } \\
\text { before purchases were made }\end{array}$ & 19 & 38 & 17 & 34 & 14 & 28 \\
\hline $\begin{array}{l}\text { Procurement procedures did consider threshold in } \\
\text { procurement }\end{array}$ & 32 & 18 & 36 & 16 & 32 \\
\hline $\begin{array}{l}\text { Tendering processes were always open to the } \\
\text { general public }\end{array}$ & 50 & 17 & 34 & 8 & 16 \\
\hline
\end{tabular}

Source: Fieldwork, 2015 
With the views of the respondent's on different aspects of procurement activities before PPA at Tamale Polytechnic were considered under Table 2, it was found that (50\%) agreed that the tendering process was always open to the public and (48\%) were of the view that Tamale Polytechnic follows due processes on procurement. On the other hand the aspect where the respondents' were least happy with was on procurement threshold (36\%). The "uncertain" column was a bit of concern as (32\%) and (28\%) on procurement threshold consideration and approval of request before purchase respectively.

It is therefore deduced from the data that the institution did not follow proper procurement processes in purchasing goods and services as well as the award of contracts prior to the introduction of the PPA 2003 (Act 663). This finding agreed with the view of Transparency International [14] that public procurement was necessary because of lack of appropriate procedures for procurement activities in the public organizations. The responses on request for procurement approval before purchases were with a mixed reaction as there was not a definitive answer in an affirmative direction. This shows that it depends on the urgency and the department in question if it falls within their budget with less budgetary implications, this is aligned to OECD [15] study which found out that public procurement as a government activity was most vulnerable to corruption.

One important element in procurement regulations is threshold. This is the maximum amount beyond which an individual cannot approve for transactions to take place. It must be sent to the institutions tender committee for approval as part of the procurement practices in the Polytechnic before the introduction of the PPA (Act 663). After the analysis of the field data, it was deduced that the procedures were not followed as $32 \%$ agreed, this confirms the studies of Eyiah and Cook [5] who said monetary thresholds were not regularly rationalised and follows. That is to suggest that procurement procedures did not consider threshold in purchases before the coming into being of the public procurement law. This finding goes in tangent with the point made by Kotoka [6] that prior to the enactment of the PPA 2003 (Act 663), Ghana National Procurement Agency (GNPA) and Ghana Supply Company Limited (GSCL) were the main agents that procured all public goods for the government since there was no comprehensive procurement guidance and that these bodies were not regulating the purchasing of goods, services and awards of contracts on behalf of public entities properly.

PPA, 2003 (Act, 663) has also ensured value for money through quality which ensures reasonable cost, durability and easy usage by the user department. This is always been done through the involvement of the user department in evaluations and delivery of the goods or service as well as the execution of contracts through tendering process. By relating this assertion to the study and using it to determine procurement practices before the enactment of the PPA 2003 (Act 663), the study asked the respondents to indicate whether tendering processes were always opened to the general public. Owing to the above revelations, it can be stated that before the enactment of the Public Procurement Act 2003 Act 663), tendering process was not opened to the general public. The net effect is that value for money could not be guaranteed as contract values were likely to be higher than normal. This result is not in line with Arrowsmith [16] who said that the main objectives of the public procurement reforms are value for money, efficiency, transparency, probity and accountability.

\section{Procurement practices after the implementation of PPA (Act 663)}

This section examined the respondent's views on procurement practices after the PPA (Act 663) implementation. The result depict preparation of procurement plan before purchases, advertised tender in daily papers, independent panel evaluate, reviewed and approve 
documents, fairness of tendering processes and procedures and entity tender committee evaluate reports and review for approval.

Table 3: One Sample Statistics

\begin{tabular}{|l|l|l|l|l|}
\hline Aspects attached to procurement activities & N & Mean & SD & Std Error Mean \\
\hline Preparation of procurement plan before purchases & 50 & 3.76 & 1.021 & 0.144 \\
\hline Advertised tender in daily papers & 50 & 3.44 & 1.163 & 0.165 \\
\hline Independent panel evaluate, reviewed and approval & 50 & 3.50 & 1.129 & 0.160 \\
\hline Fairness of tendering processes and procedures rev for & 50 & 3.70 & 0.995 & 0.141 \\
\hline $\begin{array}{l}\text { Entity tender committee evaluate reports and review } \\
\text { approval }\end{array}$ & 50 & 3.68 & 0.957 & 0.135 \\
\hline
\end{tabular}

Source: Fieldwork, 2015

As indicated in Table 3, two of the factors had mean agreement scores that were significantly different from the point of indifference, the agreement of the two factors were designed to help achieved the objects of the PPA. These included preparation of procurement plan before purchases (mean $=3.76$ ) and entity tender committee evaluation of reports and review for approval (mean $=3.70$ ). In terms of degree of consensus under the standard deviation, fairness of tendering processes and procedures $(\mathrm{SD}=0.957)$ and $(0.995)$ for entity tender committee evaluation of reports and review for approval. By implication, this finding as shown in the results suggests proper procurement procedures are being followed in the Polytechnic after the enactment of the PPA 2003 (Act 663). This seems to agree with postulations of Anvuur et al. [17] that the public organizations did not have any appropriate procedure for purchases and award of contracts before the enactment of the PPA 2003 (Act 663).

The PPA, 2003 (Act 663) has also set the standards for accountability in Ghana's procurement system. The Act establishes five basic principles upon which the public procurement is based as reported by World Bank [10]. These pillars are: the legal and institutional framework; standardized procurement procedures and tender documents; independent control system; proficient procurement staff; and anti-corruption measures. On the basis of the field data, one can say that the authorities of the Polytechnic constituted independent panel to evaluate and recommend for approval request by user departments for purchases. This therefore suggests that the Polytechnic is acting in accordance with the provisions of the PPA (Act 663).

Table 4: One Sample Test

\begin{tabular}{|c|c|c|c|c|c|c|}
\hline \multicolumn{7}{|c|}{ Test Value $=0$} \\
\hline \multirow[t]{2}{*}{ Aspects attached to procurement activities } & \multirow[t]{2}{*}{$\mathbf{t}$} & \multirow[t]{2}{*}{ df } & \multirow[t]{2}{*}{$\begin{array}{l}\text { Sig (2- } \\
\text { tailed) }\end{array}$} & \multirow[t]{2}{*}{$\begin{array}{l}\text { Mean } \\
\text { Difference }\end{array}$} & \multicolumn{2}{|c|}{$\begin{array}{c}95 \% \text { confidence } \\
\text { interval of the } \\
\text { difference }\end{array}$} \\
\hline & & & & & Lower & Upper \\
\hline Preparation of procurement plan before purchases & 26.030 & 49 & 0.000 & 3.760 & 3.47 & 4.05 \\
\hline Advertised tender in daily papers & 20.908 & 49 & 0.000 & 3.440 & 3.11 & 3.77 \\
\hline $\begin{array}{l}\text { Independent panel evaluate, reviewed and } \\
\text { approval }\end{array}$ & 21.913 & 49 & 0.000 & 3.500 & 3.18 & 3.82 \\
\hline Fairness of tendering processes and procedures & 27.190 & 49 & 0.000 & 3.680 & 3.41 & 3.95 \\
\hline $\begin{array}{l}\text { Entity tender committee evaluate reports and } \\
\text { review for approval }\end{array}$ & 26.297 & 49 & 0.000 & 3.700 & 3.42 & 3.98 \\
\hline
\end{tabular}

Source: Fieldwork, 2015

The study identified five factors under the aspects attached to procurement activities in Table 4 using One Sample t-Test to analyse it. The positive t value of all the factors $(26.030,20.908$, $21.913,27.190$ and 26.297) respectively for preparation of procurement plan before purchases, advertised tender in the daily papers, independent panel evaluation, review and approval, fairness of tendering processes and procedures and entity tender committee 
evaluate reports and review for approval. The p-value from this statistic is 0.000 and that is less than 0.05 (the level of significance for the test). Since $p<0.05$, the result reject the null hypothesis that the sample mean is equal to the hypothesis population mean and conclude that all the five factors are statistically significantly different than the average. Based on the result it can be said that Tamale Polytechnic adhered to the rules and regulation of the PPA (Act 663) to a large extent so far as those variables are concerned in its procurement activities.

\section{Effects of PPA (Act 663)}

Table 5: Ranking of PPA effects on procurement practices identified by the respondents

\begin{tabular}{|l|l|}
\hline Factors & Ranking \\
\hline Sanity in procurement procedures to all suppliers & 1 \\
Laws and regulations by PPA are applied in Tamale Polytechnic & 1 \\
Public procurement monitoring and audit reports seriously adhered to & 2 \\
Training of staff on procurement activities & 3 \\
Number of respondents & 50 \\
Coefficient of concordance (W) & $0.351(35.10 \%)$ \\
\hline
\end{tabular}

Personnel can use to benefit their personal selfish interest example the application of sole sourcing.

As far as training of staffs is important it was ranked the least as the majority of them are professionals and very literate to relate to PPA (Act 634) in terms of its implementation, this does not discounted updating their knowledge and skill in procurement related activities through seminars, workshops and conferences. This therefore reflects the view of Knight et al. [19] that in most developing countries, the procurement function is transitioning from a clerical non-strategic unit to an effective socio-economic unit that is able to influence decisions and add value through collective training and participation of officers of the institutions where the procurement is practiced.

It is clear that the overall result of Table 5 gives a mixed reaction on the effects of the PPA (Act 634) on procurement practices of Tamale Polytechnic. Cultural and behavioural attitudes cannot be ruled out as this is a challenge to the status quo they were used to before the implementation of the PPA (Act 634). On the basis of the above result, it can be stated that though the institute has taken the steps to duly adhere to the laws and regulations of the PPA but more need to be done to achieve the objectives of the Act in terms of transparency, accountability and value for money. The Coefficient of Concordance (W) $35.10 \%$ is an indication that there is higher level of disagreement between the staffs of Tamale Polytechnic on the factors considered under the effects of PPA on its procurement activities. This can be inferred as low or partial adherence to the PPA hence value for money may be compromise thereby defeating the object of the PPA.

\section{Implementation challenges on PPA (Act 663)}

Table 6: Ranking on implementation challenges on PPA (Act 663) identified by the respondents

\begin{tabular}{|l|l|}
\hline Factors & Ranking \\
\hline Lack of funds to effect early payment to suppliers & 1 \\
Interference of top management in procurement activities & 2 \\
Lack of funds to organize on the job training for procurement staff & 3 \\
Inexperience staff to properly implement the PPA & 4 \\
Number of respondents & 50 \\
Coefficient of concordance (W) & $0.675(67.5 \%)$ \\
\hline
\end{tabular}

\section{Source: Fieldwork 2015}

The study identified four main implementation challenges on the PPA (Act 634). These are: lack of funds to effect early payment to suppliers, interference of top management in procurement activities, lack of funds to organise on the job training for procurement staff and 
inexperience staff to properly implement the PPA. The respondents were asked to rank these challenges and the result of the ranking is presented in Table 6. The $\mathrm{F}$ tests for degree of agreement or concordance (W) between the rankings of the effects with regards to the PPA by the respondent staff is $(67.50 \%)$ which is fairly high.

The results shows that lack of funds to effect early payment to suppliers was a challenge facing effective implementation of public procurement in the Polytechnic. As captured in the literature, the Public Procurement Authority has also given some responses in order to help address some of the challenges in the implementation of the PPA, 2003(Act 663) by the general public and the implementing institutions. This is therefore recognition by the law that some institutions were likely to be faced with financial constraints which eventually would make early payments difficult. Management of Tamale Polytechnic must embark on priority buying and in smaller quantities for sensitive items in the short term while also drafting a procurement contract that will help the institute to benefit from economic of scale by having a consignment buying within a specify period and source for a supplier who can fit to this by rewarding them with long contract agreement based on performance indicators to benefit the two by taking the path of partnering procurement..

The second challenge was interference of top management in the procurement activities of the Tamale Polytechnic. Digging further into the establishment of implementation challenges of the PPA 2003 (Act 663) in Tamale Polytechnic, the study asked the respondents to indicate their level of agreement or disagreement with the assertion that there was interference of top management in procurement activities. In the establishment of the extent to which this phenomenon existed in the Polytechnic, the respondents ranked it as second to lack of funds to effect early payment to suppliers. As captured in the literature, Azeem [11] was of the view that interference by authorities of public institutions on procurement activities have been cited as some of the crucial factors that challenges the procurement reforms implementation.

In addition to the above was the issue of lack of finance to organize on job training for procurement staff as a challenge facing the effective implementation of the PPA 2003 (Act 663) in the Polytechnic? The field data however revealed that there was lack of funds to organise on-job training for staff of the Polytechnic and as such, this was seen as a challenge facing the smooth implementation of the PPA in the institution. In addition this can be addressed by putting systems, procedure and instructions to be followed to execute any procurement activity, alongside of this is mentoring the inexperience staff which is as good as any form of training. Moreover procurement code of ethics and professionalism must be visible and inculcate in them as part of their induction training and on-going career development.

As part of issues considered in the assessment of implementation challenges of the PPA 2003 (Act 663), the study elicited views of the respondents on the extent to which inexperience staff to properly implement the PPA Act 663 could constitute a challenge in Tamale Polytechnic. The responses revealed that this was not a challenge in the Polytechnic as evidently was ranked the last one in Table 6. This finding is a reflection that the procurement unit of the Polytechnic has the requisite staff to effectively ensure smooth implementation of the PPA in the Polytechnic. This revelation reflects the recommendation of Adjei [3] that effective implementation of the Public Procurement Act requires that public institutions employ personnel with the requisite qualifications to run the procurement units.

The Coefficient of Concordance (W) $67.50 \%$ is fairly high, indicates that the staffs of Tamale Polytechnic are in almost a complete agreement on the factors that are outlined in Table 6 . This 
is a worrying situation as it served as a barrier to achieve the object of the PPA. If not resolved and managed it well can serve as a platform for fraudulent officials to hijack the wonderful objects of the PPA in terms of transparency, accountability and value for money.

\section{CONCLUSION AND RECOMMENDATION}

From the results of the study, it can be concluded that majority of the staffs have Master Degree which is characteristics of tertiary educational institution hence must have adequate knowledge of the study. In addition, almost all the staffs under the study were full time employees and their length of service is five to ten years. Prior to PPA, the tendering process was open to the general public though but the process was not strictly followed thereby creating inconsistency on proper assessment on tender documents for approval. PPA effects on procurement practices on laws and regulations were partially adhered to thereby not ensuring sanity in procurement to all suppliers. The implementation challenges brought about the interference of top management personnel and not having the funds to effect early payment.

The PPA as a document serves as a major point of reference and inference so far as public procurement is concerned in Ghana. Notwithstanding the object of the PPA, one of the weaknesses of the PPA is no clear procedures for emergency procurement. The study concludes based on the results that Tamale Polytechnic partially adhered to the PPA. The revelation of significant degree of non-adherence with the requirement of the PPA directives implies that the cost of non-adherence of the PPA will affect negatively value for money where its direct impact will include: not encouraging better procurement practices, transparency and fair competition of the processes cannot be guarantee. This study is of the view that as circumstances changes couple with lessons learnt since the inception of the PPA thirteen years ago there is the need for more initiatives from the Public Procurement Authority than the prescriptive requirements of the PPA. It has to inject and enforce prudent usage of public funds and strict penalty for non-adherence irrespective of the institution, personalities or the political affiliation of it, this should not be compromise to achieve the intent of the PPA.

This paper provides some insight into public procurement activities of Tamale Polytechnic in line with the PPA, based on the conclusion, the paper suggests that management of the Polytechnic should allow the procurement unit to operate freely without any form of interference as this will enable the unit to discharge its duties as sanctioned by the Public Procurement Act 2003 (Act 663). Moreover management must show leadership and commitment to the PPA and use it as a tool to reduce and if possible fight against corruption.

\section{References}

1. World Bank (1996) “Ghana 1996 Country Procurement Assessment Report” Washington D.C. The World Bank.

2. Suleiman, Y. (2010), Overview of public procurement reforms in Commonwealth Africa: strategy, successes and challenges. A paper presented at Public Procurement Forum at St. Lucia, the Caribbean

3. Adjei, A. B. (2005) Public Procurement Authority: What are we learning from different approaches to monitoring capacity and development? An Assessment Tool for Public Procurement System and its application to monitoring Capacity and Performance of the Procurement System in Ghana, Accra.

4. World Bank, (1997). Guidelines: Selection and Employment of Consultants by the World Bank Borrowers, Washington, DC: The World Bank.

5. Eyiah, A. and Cook, P. (2003). Financing small and medium-scale contractors in developing countries: A Ghana case study. Construction Management and Economics, 21(4), pp. 357-367. 
6. Kotoka, F. A. (2012). Assessing the level of Compliance with the Public Procurement Act 2003 (Act 663) in Public Entities in Ashanti Region of Ghana. Unpublished Commonwealth Executive Masters in Public Administration thesis, Kwame Nkrumah University of Science and Technology.

7. Hunja, R. R. (2003). Obstacles to public procurement reform in developing countries. The Netherlands: Kluwer International.

8. Evenett, S. and Hoekman, B. (2005). International cooperation and the reform of public procurement policies. Policy, Research working paper: no. WPS 3720. Washington DC: World Bank.

9. Ameyaw, C., Mensah, S. and Osei-Tutu, E. (2012) Public Procurement in Ghana: The Implementation Challenges to the Public Procurement Law, 2003 (Act, 663) International Journal of Construction Supply Chain Management Vol. 2 No. 2. (pp. 55-65). DOI: 10.14424/ijcscm202012-55-65

10. World Bank, (2003). Ghana 2003 Country Procurement Assessment Report, Washington, DC: Ghana Country Department. The World Bank.

11. Azeem, V. (2007) "Impact of the Public Procurement Act, 2003 (Act 663)" in Ghana integrity initiatives perspective. Paper presented at a special forum on improving Efficiency and transparency in Public Procurement through Information Dissemination.

12. Adusei, C. and Awunyo-Vitor, D. (2015), Implementation challenges of the Public Procurement Act by Selected Metropolitan, Municipal and District Assemblies in the Ashanti Region, Ghana. iBusiness, 7, 3950. http://dx.doi.org/10.4236/ib.2015.71005

13. Bower, A. G. (1993). Procurement Policy and Contracting Efficiency. International Economic Review, 34(4):873-901. DOI: $10.2307 / 2526970$

14. Transparency International (2006). Handbook for Curbing Corruption in Public Procurement. Berlin

15. OECD (2007). Integrity in Public Procurement: Good Practice from A to Z. Organisation for Economic Cooperation and Development, Paris.

16. Arrowsmith, S. (2005). The Law of Public and Utilities Procurement, 2nd edition. Sweet and Maxwell. London

17. Anvuur, A., Kumaraswamy, M.M. and Male, S. (2006) Taking forward public procurement reforms in Ghana, CIB W 107 Construction in Developing Economies Symposium, "Construction in Developing Economies: New Issues and Challenges”, 18-20 January 2006, Santiago, Chile, CD Rom 9 pages.

18. Schiele, J.J. and McCue, C.P. (2006). Professional service acquisition in public sector procurement, International Journal of Operations and Productions Management, 26(3), 300-325. http://dx.doi.org/10.1108/01443570610646210

19. Knight, L., Harland, C., Telgen, H., Thai, K.V.., Callender, G. and McKen, K. (2007), Public Procurement: International Cases and Commentary. Routlegde, Taylor \& Francis Group. London 